\title{
Influence of a Menadione Derivative on Banana Panama Disease Development and Yield Enhancement
}

\author{
M. Fernández-Falcón*, C.E. Alvarez, R. Gorrín, M.M. Hernández and A.A. Borges
}

Instituto de Productos Naturales y Agrobiología, C.S.I.C., Astrofísico Francisco Sánchez, 3, Apdo. s/n, 38206 La Laguna, Tenerife, Canary Islands, Spain

\begin{abstract}
One derivative (Param-A) of a water-soluble compound of 2-methyl-1,4-naphthoquinone has been commercially launched to induce resistance against Panama disease in bananas, caused by Fusarium oxysporum f. sp. cubense. This paper reports on a long-term experiment in order to verify the improvements that Param-A can provide in unfavourable banana culture conditions, such as those of a plantation seriously affected by Panama disease and in a soil with deficient drainage and high salinity. The results demonstrated that Param-A sprays decreased disease occurrence and delayed symptom appearance significantly. Sprays of Param-A every 60 days shortened the time from plant flowering to fruit cutting, and resulted in significantly higher yields.
\end{abstract}

\section{INTRODUCTION}

Fusarium wilt of banana is widely regarded as one of the most destructive plant diseases. The soilborne fungus Fusarium oxysporum f. sp. cubense causes Panama disease, by hindering sap movement in the host plant (Beckman APS 1990) [1]. Four races of the pathogen are currently recognized (Stover FWB 1990) [2]. Although Cavendish cvs. are resistant to races 1 and 2 of the pathogen, race 4 can affect these cultivars (Su PD 1986) [3] as well as cultivars that are susceptible to race 1 and race 2 , in subtropical bananagrowing regions (Jones FDRCP 1999) [4]. The continued use of the Cavendish cultivars now threatens banana production in these regions, and producers in the tropics, mindful of disastrous epidemics which occurred with Gros Michel cultivar, are concerned that race 4 or a similar one might develop in their areas (Ploetz FWB 1990) [5].

Chemical control, flood fallowing, crop rotation and the use of organic amendments have not been effective in managing this disease (Jones FDRCP 1999) [4]. It is now generally accepted that the only effective means of control is by host resistance (Moore MDFS 1995) [6]. Our research group has been working on plant resistance induction, and major efforts have been dedicated to study Panama disease in the Canary Islands (Borges F 1983 [7]; Borges BN 1991 [8]).

Tylose occlusions of xylem vessels is considered as a defense mechanism against attack by Fusarium races in resistant banana cultivars that prevent the upward spread of the fungus. Indole-acetic-acid is one positive host factor in Beckman time-space model of host-parasite interactions (Beckman TNWS 1987 [9]; Beckman FWB 1990 [1], Beckman PMPP 2000 [10]). Experiments in pots with soil and in hydroponic systems have shown that IAA sprays

*Address correspondence to this autor at the Instituto de Producto Naturales y Agrobiología del Consejo Superior de Investigaciones Científicas, Spain; Fax: 34 922260135; Tel: 34 922256847; E-mail: mfernandez@ipna.csic.es significantly decreased severity and incidence of Fusarium wilt (Fernández-Falcón F 2004) [11]. The results obtained from our research show that a water-soluble compound of 2methyl-1,4-naphthoquinone or menadione derivatives induce resistance against Panama disease (Borges-Pérez P 1996 [12]; Lyon IRPD 2007 [13]), which acts by modulating endogenous IAA levels in the plant. One derivative (Param-A) is now available on the market. Banana plants treated with this resistance activator are capable of changing the dynamics of accumulation (amount and rate of biosynthesis) of a phytoalexin, 2-hydroxy-9-(p-hydroxyphenyl)-phenalen-1one, biosynthesized by the banana plant during pathogenesis (Borges JAFC 2003) [14].

Panama disease severity is increased by stress situations that generate a lack of vigor in the plant, such as by long flooding periods, unbalanced nutrition, low temperatures, low quality water, high soil salinity, etc. (Stover BPAD 1972 [15]; Galán LFTS 1992 [16]). Furthermore, plants produced by tissue culture suffer increased susceptibility to the disease when they are planted in the field (Promusa P 1999) [17].

The objective of this work was to evaluate any improvement that Param-A can provide in very unfavourable banana culture conditions, such as those of a plantation seriously affected by Panama disease in a soil with deficient drainage and high salinity, and assess its effect on banana life cycle and production.

\section{MATERIAL AND METHODS}

Assay description.- Ex vitro banana plants of the local clone 'Gruesa Palmera' (Dwarf Cavendish) were used in an experiment conducted from April 2003 to March 2005. In order to evaluate the effect of Param-A on the whole cycle of banana production, evaluation was separated into 2 stages. Stage 1 was carried out in greenhouses of the enterprise CULTESA that supplies banana plants from in vitro culture. Stage 2 corresponds to the field part of the assay. 


\section{Stage 1}

Banana preparation in greenhouse. Ex vitro banana were planted in greenhouse, where 400 of them received foliar sprays of $1 \mathrm{ml}$ Param-A in $1 \mathrm{~L}$ water every 15 days. Another 400 plants (control) were sprayed with water alone at 15 day-intervals.

\section{Stage 2. Field Assays}

Plants treated with Param-A and those of the control that showed better development were transplanted to a field plot situated in a farm of the first zone type (less than $100 \mathrm{~m}$ height), at the South of Tenerife, with drip irrigation, and where depurated water was used for irrigation. This plot had a soil (Entisol Torriarents) with low drainage and high salinity, conditions that favor Panama disease development. The year previous to the assay this plot had a $60 \%$ disease incidence confirmed with the isolation of the pathogen Fusarium oxysporum f. sp. cubense.

Physico-chemical characteristics of the original soil

\begin{tabular}{|c|c|c|c|c|c|c|c|c|}
\hline \multirow[t]{2}{*}{ Texture } & \multirow[t]{2}{*}{ pH } & \multirow{2}{*}{$\begin{array}{l}\text { O.M. } \\
\text { g kg-1 }^{-1}\end{array}$} & \multirow{2}{*}{$\begin{array}{c}\mathrm{P}_{2} \mathrm{O}_{5} \\
\mathrm{mg} \mathrm{kg}^{-1}\end{array}$} & \multicolumn{4}{|c|}{$\begin{array}{c}\text { Available Cations } \\
\qquad \mathrm{cmol} \mathrm{kg}^{-1}\end{array}$} & \multirow{2}{*}{$\begin{array}{c}E C \\
d S ~ m^{-1}\end{array}$} \\
\hline & & & & $\mathrm{Ca}$ & Mg & $\mathrm{Na}$ & $\mathbf{K}$ & \\
\hline Clay Loam & 5.8 & 18.0 & 135 & 21.2 & 10.4 & 3.5 & 4.9 & 8.54 \\
\hline
\end{tabular}

This stage was divided in two parts: 1) Banana plant adaptation to field conditions, and 2) development to production cycle. Treatments in each part consisted of four replications, following a randomized block design, with 75 plants per replication in the first part and 25 plants per replication in the second part, chosen at random among the best developed plants in the first part.

The first part was the most critical and lasted 3 months. Control plants came from the control treatment in Stage 1, and were sprayed with water only. Param-A at the dose of $1 \mathrm{ml} \mathrm{L}^{-1}$ was then sprayed every 15 days or 30 days to plants coming from the Param-A treatment in stage 1.

Plants of the control and of the Param-A at 15 days treatment, which in the first part of the present stage showed the best development, were chosen for the second part of the stage. Plants from the previous control went on without receiving Param-A, while those treated with Param-A were sprayed with $1 \mathrm{ml} \mathrm{L}^{-1}$ of this product, a) every 60 days (hereafter referred to as P60), b) every 90 days (hereafter referred to as P90). Doses and time schedules of treatments were chosen in accordance with previous studies (see introduction).

\section{Plant Development Measurements}

Twenty plants from every replication were chosen at random to establish development variables. Pseudostem circumference and plant height were determined at 3, 7 and 11 months after transplanting plants to the field plot. Flowering dates were recorded every $15 \mathrm{~d}$ after the first flowering plant was detected. Harvest time, bunch weights and number of plants affected by Panama disease were also recorded. Af- fected Panama diseased plants were counted when they presented marked visual symptoms.

\section{Statistical Analysis}

A one-way analysis of variance test was performed for determining if significant differences were present among all the measured parameters in each stage. Percentage data were transformed with the Transform Options of the statistical software. Statgraphics Sgwin 4.0 Software was used (Statgraphics SPW 1999) [18]. Significantly different treatment means were separated with a Tukey multiple comparison test. Time series analysis was performed by the JonckheereTerpstra test (Bewick CC 2004) [19].

\section{RESULTS AND DISCUSSION}

\section{Stage 1}

The Greenhouse study (Table 1) showed no differences in growth among the plants from the control and those that received Param-A, probably because culture and environmental conditions were optima for banana plantlets growth.

Table 1. Mean Values of the Measured Parameters at the End of Stage 1 Cycle

\begin{tabular}{|c|c|c|c|c|}
\hline Treatment & $\begin{array}{c}\text { Number of } \\
\text { Leaves Issued }\end{array}$ & $\begin{array}{c}\text { Leaf Width } \\
(\mathbf{c m})\end{array}$ & $\begin{array}{c}\text { Leaf Length } \\
(\mathbf{c m})\end{array}$ & $\begin{array}{c}\text { Plant Height } \\
(\mathbf{c m})\end{array}$ \\
\hline \hline Param- A 15 d & 7,5 & 13,5 & 22,3 & 12,4 \\
\hline Param-A 30 d & 7,7 & 13,0 & 21,9 & 13,3 \\
\hline Control & 7,7 & 13,2 & 22,2 & 12,8 \\
\hline
\end{tabular}

\section{Stage 2. Field Assays}

\section{Part 1. Plant Adaptation to Field Conditions}

No significant differences in plant development were observed between Param-A 15 treatment and the control, but the contrary was detected on the plants that received ParamA 30 treatment. On the other hand, Param-A 15 treatment presented the lowest disease percentage, and Param-A 30 the highest (Table 2). These facts suggest that the quantities of Param-A supplied by Param-A 30 treatment were excessive, what can produce effects opposite to the expected ones.

Table 2. Mean Values of the Measured Parameters at the End of the Adaptation Cycle of the Banana Plants to Field Conditions (11 Months after Transplanting)

\begin{tabular}{|c|c|c|c|c|c|}
\hline Treatment & $\begin{array}{c}\text { Plant } \\
\text { Height } \\
(\mathbf{c m})\end{array}$ & $\begin{array}{c}\text { Pseudostem } \\
\text { Circumference } \\
(\mathbf{c m})\end{array}$ & $\begin{array}{c}\text { Number } \\
\text { of Leaves } \\
\text { Produced }\end{array}$ & $\begin{array}{c}\text { Percentage } \\
\text { of Diseased } \\
\text { Plants }\end{array}$ & $\begin{array}{c}\text { \% of Disease } \\
\text { Reduction } \\
(\mathbf{1})\end{array}$ \\
\hline \hline Param-A 15 d & $58.56 \mathrm{ab}$ & $204.2 \mathrm{ab}$ & $12.55 \mathrm{a}$ & 1.78 & 60.1 \\
\hline Param-A30 d & $55.97 \mathrm{~b}$ & $194.3 \mathrm{~b}$ & $11.90 \mathrm{~b}$ & 6.69 & -50.0 \\
\hline Control & $61.17 \mathrm{a}$ & $216.0 \mathrm{a}$ & $12.50 \mathrm{ab}$ & 4.46 & -- \\
\hline
\end{tabular}

(1) Relative percentage in relation to the control (100 - disease reduction by the treatment / Control).

Values within the same column followed by the same letters are not significantly different at the $\mathrm{p}=0.05$ level. 


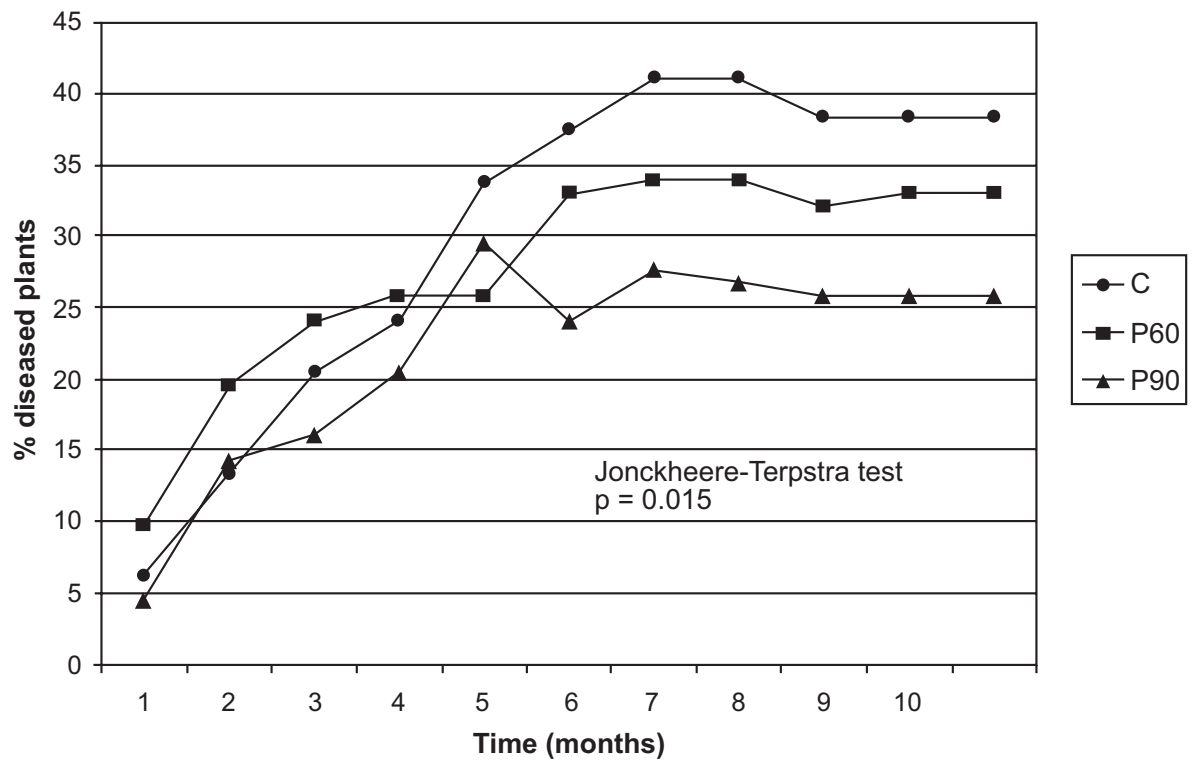

Fig. (1). Percentage of diseased plants between 1 and 11 months after planting.

\section{Part 2. Development to Production Cycle}

\section{Panama Disease Development}

Fig. (1) shows the development of the disease over time in the different treatments. The control treatment presented the higher disease indexes, with $38.4 \%$ of diseased plants at the end of the experimental period, followed by the P60 treatment, with $33 \%$ of diseased plants.

P90 gave the best results, with $25.9 \%$ of diseased plants. These data show that the Panama disease was significantly reduced by $32.1 \%$ with P90 applications (Table 3). Disease symptoms appeared later in Param-A treatments, especially with P90 (Fig. 1). For example, when the control displayed $33.9 \%$ diseased plants (fifth month, May), this percentage was observed 2 months later with P60, while plants that received P90 never reached that percentage.

Table 3. Percentage of Panama Disease Reduction

\begin{tabular}{|c|c|c|}
\hline Treatment & $\begin{array}{c}\text { Percentage of Dis- } \\
\text { eased Plants }\end{array}$ & $\begin{array}{c}\text { \% of Disease } \\
\text { Reduction (1) }\end{array}$ \\
\hline \hline Param-A 60 d & $33.0 \mathrm{~b}$ & $14.1 \%$ \\
\hline Param-A 90 d & $25.9 \mathrm{c}$ & $32.6 \%$ \\
\hline Control & $38.4 \mathrm{a}$ & -- \\
\hline
\end{tabular}

(1) Relative percentage in relation to the control (100 - disease reduction by the treatment / Control).

Values within the same column followed by the same letters are not significantly different at the $\mathrm{p}=0.05$ level.

\section{Effect on Flowering}

The first survey of flowered plants was made on 30 August 2004, and was then repeated at fortnightly intervals. The P60 treatment began to show a significant difference in terms of flowering from the control on the fourth survey (Table 4).
P90 plants also began to show significantly higher flowering percentage than the control on the $6^{\text {th }}$ survey. These trends persisted until the end of the surveys, when the difference among P60 treated plants and those of the control was of $15.68 \%$. P90 then presented $7.7 \%$ more flowered plants than the control.

Table 4. Mean Percentage of Flowered plants According to Treatment and Flowering Date

\begin{tabular}{|c|c|c|c|}
\hline Date & Control & Param-60 & Param-90 \\
\hline \hline $30 / 08 / 04$ & 4.5 & 4.5 & 5.4 \\
\hline $13 / 09 / 04$ & 14.3 & 17.8 & 13.4 \\
\hline $06 / 10 / 04$ & 30.3 & 37.5 & 34.8 \\
\hline $20 / 10 / 04$ & 39.3 & 43.7 & 42.8 \\
\hline $4 / 11 / 04$ & 44.6 & 50.9 & 48.2 \\
\hline $17 / 11 / 04$ & 46.4 & 55.3 & 52.3 \\
\hline $1 / 12 / 04$ & 49.1 & 57.1 & 54.4 \\
\hline $15 / 12 / 04$ & 52.7 & 58.0 & 55.3 \\
\hline $03 / 01 / 05$ & 52.7 & 62.5 & 57.1 \\
\hline $19 / 01 / 05$ & 52.7 & 62.5 & 57.1 \\
\hline
\end{tabular}

Significant level among treatments of Jonckheere-Terpstra test $=0.02$.

When $52.7 \%$ of P60 treated plants flowered, a similar percentage was reached by control plants nearly a month later. These data suggest an advancement of flowering by 4 weeks in plants receiving $\mathrm{P} 60$, in spite of the higher surface with solar illumination in the control plot, due to the higher number of dead plants therein caused by the Panama disease. Illumination means a higher growing index, which results in flowering advancement (Galán LFTS 1992) [16]. As far as comparison among plants having received Param-A is concerned, P90 plants showed a lower flowering advancement, 
which probably took place because of the less incidence of Panama disease in this treatment, and its concomitant decrease of solar illumination per plant.

It is important to emphasize that it was not possible to count 100 per cent of flowered plants because some plants used to make measurements died before flowering, due to the Panama disease.

\section{Harvest Times}

Mean percentage of cropped bunches according to cutting dates are represented in Table 5. From the second cutting onwards, P60 treatment was significantly different from the other treatments, with 54\% cut bunches. Though P90 applications produced a higher percentage $(25 \%)$ of cut bunches than the control $(16.7 \%)$, the difference did not reach a significant level.

The greatest differences appeared at the third cutting (14 February 2005), when $75 \%$ of P60 treated plants were ready to harvest, compared with only $37.5 \%$ of plants from P90 treatment and $33.3 \%$ of control plants. Advancement in bunch cutting by P60 was also significant in relation to the control, within an interval of 21 to 24 days.

Table 5. Harvested Bunches Over Time (Percentage of Total Plants Per Treatment)

\begin{tabular}{|c|c|c|c|c|c|}
\hline \multirow{2}{*}{ Treatments } & \multicolumn{5}{|c|}{ Date } \\
\cline { 2 - 6 } & $\mathbf{2 4 / 0 1 / 0 5}$ & $\mathbf{0 1 / 0 2 / 0 5}$ & $\mathbf{1 4 / 0 2 / 0 5}$ & $\mathbf{2 5 / 0 2 / 0 5}$ & $\mathbf{7 / 0 3 / 0 5}$ \\
\hline \hline Control & 16.7 & 16.7 & 33.3 & 54.2 & 100 \\
\hline Param-A 60 d & 29.2 & 54.2 & 75.0 & 91.7 & 100 \\
\hline Param-A 90 d & 16.7 & 25.0 & 37.5 & 66.7 & 100 \\
\hline
\end{tabular}

Significant level among treatments of Jonckheere-Terpstra test $=0.05$.

\section{Production}

Fig. (2) shows the mean bunch weight per plant of the different treatments. Once again, the yields with P60 treatment were superior than those of the other treatments, with significantly higher bunch weight, with a mean of $43.3 \mathrm{~kg}$ against the $42.0 \mathrm{~kg}$ in the control and the $41.5 \mathrm{~kg}$ with the P90 treatment.

Taking these data and those of the Panama disease incidence into account, Fig. (2) represents the mean yield/ha. Data for this figure were calculated relating the number of plants that remained alive over time in each treatment, and the mean weight of harvested bunches, and estimating a plantation of 2000 banana plants per hectare. Due to the higher number of healthy plants in the Param-A treated plots, statistical analysis proved significantly higher yields of plants from these treatments $\left(61478 \mathrm{~kg} \mathrm{ha}^{-1}\right.$ for $\mathrm{P} 60$, and $65351 \mathrm{~kg}$ for P90) in comparison with the control plants (46291 kg ha' ${ }^{-1}$ ).

The recommendations for continuing to use in the field the chemical tested (Param-A) as a control agent of Panama disease, advancement of flowering time and yield enhancement is to spray this product on the leaves of the banana plants every 60 days, at a concentration of $1 \mathrm{ml}$ per $1 \mathrm{~L}$ of water.

$\underline{\text { Soils }}$

No significant differences were found in measured soil properties before and after treatments.

\section{ACKNOWLEDGEMENTS}

We acknowledge the enterprise CULTESA (Cultivos Vegetales In Vitro de Tenerife, S.A.) for kindly supply the banana plants and provide their greenhouses for the two first stages of this study. We acknowledge Mrs. Pauline Agnew for editing the English version of this paper.

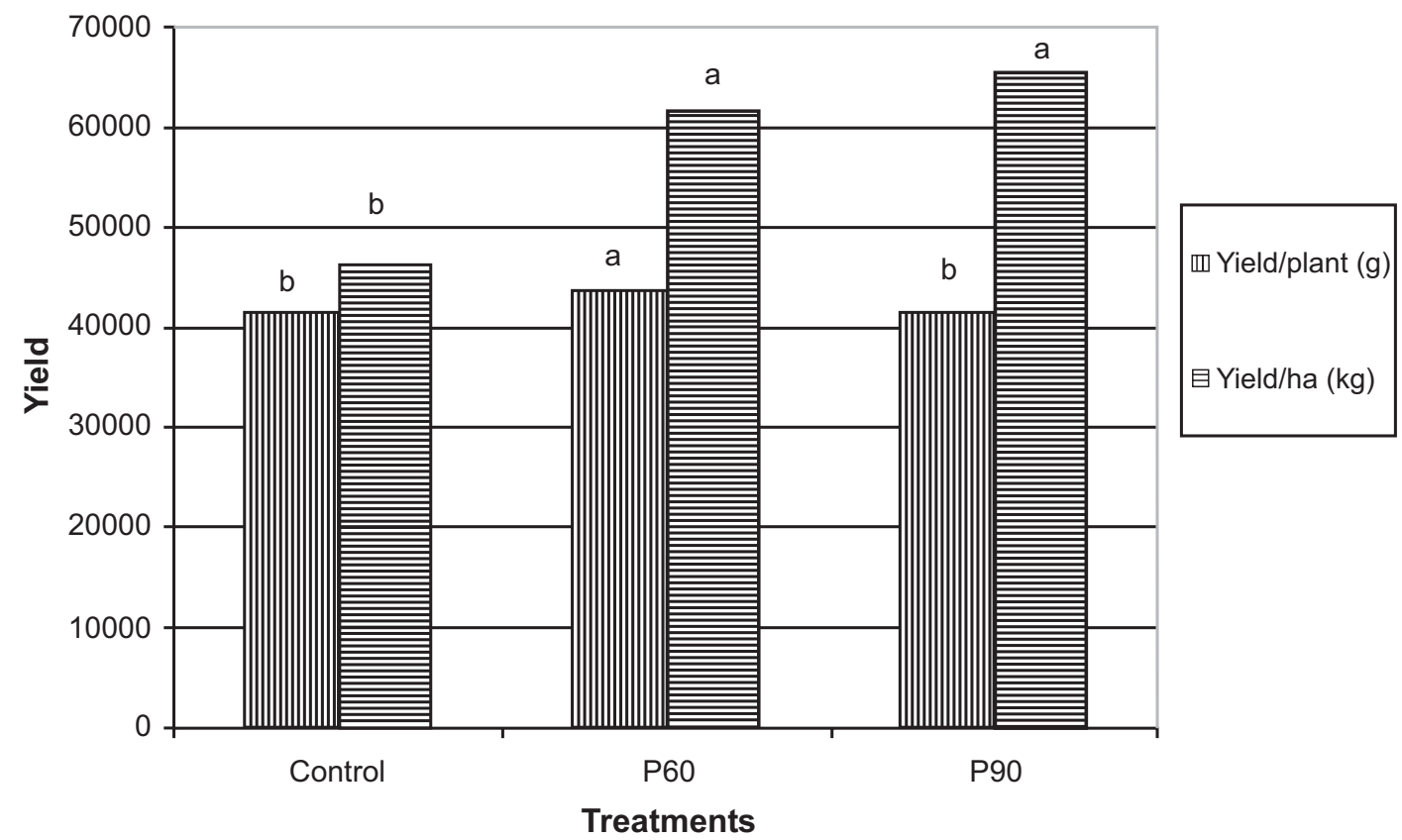

Fig. (2). Yield per plant $(\mathrm{g})$ and theoretical yield per hectare $(\mathrm{kg})$ of the different treatments. Different letters on columns of the same variable denote significant differences at $\mathrm{p}=0.05$. 


\section{REFERENCES}

[1] Beckman CH. Host responses to the pathogen. In: Ploetz RC, Ed. Fusarium Wilt of Banana. MN, St. Paul: APS Press: American Phytopathological Society 1990; pp. 93-105.

[2] Stover RH. Fusarium wilt of bananas: some history and current status of the disease. In: Ploetz RC, Ed. Fusarium Wilt of Bananas. Minnesota, St. Paul: APS Press 1990; pp. 1-7.

[3] Su HJ, Hwang S, Ko KH. Fusarial wilt of cavendish banana in Taiwan. Plant Dis 1986; 70: 814-8.

[4] Jones DR. Diseases of banana, Abaca and Enset. In: Jones DR, Ed. Fungal diseases of the root, corm and pseudostem. New York: CAB International 1999; pp. 142-72.

[5] Ploetz R. Preface. In: Ploetz RC, Ed. Fusarium Wilt of Banana. MN. St. Paul: APS Press: American Phytopathological Society 1990; pp. 135-138.

[6] Moore NY, Bentley S, Pegg KG, Jones DR. Fusarium wilt of banana. Musa Disease Fact Sheet No.5, INIBAP: France 1995.

[7] Borges-Pérez A, Trujillo del Castillo I, Gutiérrez-Jerez F, AnguloRodríguez D. Estudio sobre el mal de Panamá en las Islas Canarias. II.- Influencia de los desequilibrios nutritivos P-Zn y K-Mg del suelo, en la alteración de los mecanismos de resistencia de la platanera (Cavendish enana) al Mal de Panamá. Fruits 1983; 38: 755-8.

[8] Borges A, Fernández M, Bravo JJ, Pérez JF, López I. Enhanced resistance of banana plant (Dwarf Cavendish) to Fusarium oxysporum f. sp. cubense by controled $\mathrm{Zn}$ nutrition under field conditions. Banana Newsl 1991; 14: 24-6.

[9] Beckman CH. The nature of Wilt Diseases of Plants. MN, St. Paul: APS Press: The American Phytopathological Society 1987.
[10] Beckman CH. Phenolic- storing cells: Keys to programmed cell death and periderm formation in wilt disease resistance and in general defense responses in plants. Physiol Mol Plant Pathol 2000; 57: 101-10.

[11] Fernández-Falcón M, Borges AA, Borges-Pérez A. Response of Dwarf Cavendish banana plantlets to inoculation with races 1 and 4 of Fusarium oxysporum f.sp. cubense (FOC) at different levels of Zn nutrition. Fruits 2004; 59: 319-23.

[12] Borges-Pérez A, Fernández-Falcón M. Utilization of compositions which contain menadione for the stimulation of plant metabolism in order to induce their resistance to pathogen and pest and or accelerate their blooming. Patent WO 9628026. 1996.

[13] Lyon G. Agents that can elicit induced resistance. In: Walters D, Newton A, Lyon G, Eds. Induced resistance for plant defence. Oxford, UK: Blackwell Publishing 2007; pp. 9-29.

[14] Borges AA, Borges-Pérez A, Fernández-Falcón M. Effect of menadione sodium bisulfite, and inducer of plant defenses, on the dynamic of banana phytoalexin accumulation during anthogenesis. J Agric Food Chem 2003; 51: 5326-8.

[15] Stover RH. Banana plantain and abaca diseases. Kew, Surrey: Commonwealth Mycological Institute 1972; p. 316.

[16] Galán V. Los frutales tropicales en los subtrópicos. II. Madrid: Plátano Mundi-Prensa 1992; p.173.

[17] Promusa. Marchitamiento por Fusarium del banano: hacia una producción sostenible. Promusa 1999; 4: 1-5.

[18] Statgraphics. Statgraphics Plus for Windows 4.0. Rockville: Statistical Graphics Corporation 1999.

[19] Bewick V, Cheek L, Ball J. Statistics review 10: Further non parametric methods. Crit Care 2004; 8: 196-9.

(C) Fernández-Falcón et al.; Licensee Bentham Open.

This is an open access article licensed under the terms of the Creative Commons Attribution Non-Commercial License (http://creativecommons.org/licenses/ by-nc/3.0/) which permits unrestricted, non-commercial use, distribution and reproduction in any medium, provided the work is properly cited. 